PATIK : Jurnal Hukum

https://ejournal.uhn.ac.id/index.php/patik

Volume 10 Nomor 01, April 2021 Page : 51 - 60

p-issn : $2086-4434$

\title{
ANALISIS HUKUM PENJATUHAN PIDANA TERHADAP PELAKU YANG DENGAN SENGAJA MELAKUKAN PENAMBANGAN PASIR DI WILAYAH PESISIR DAN PULAU-PULAU KECIL TANPA IZIN (Studi Putusan No. 113/Pid.B/2018/PN.Ffk)
}

\author{
Desy Damayanti Elisabeth Sitanggang, Ojak Nainggolan, Jinner Sidauruk \\ Fakultas Hukum, Universitas HKBP Nommensen \\ ojaknainggolan@uhn.ac.id
}

\begin{abstract}
Abstrak
Tindakan mengadili suatu tindak pidana merupakan persoalan terpenting dan merupakan pusat dari sistem peradilan pidana. Rumusan masalah yang akan menjadi pokok bahasan dalam penulisan ini adalah bagaimanakah dasar pertimbangan hakim dalam menjatuhkan hukuman terhadap pelaku yang dengan sengaja melakukan penambangan pasir di wilayah pesisir dan pulau-pulau kecil tanpa izin ? (Studi Putusan Nomor 113/Pid.B/2018/PN.Ffk). Penelitian ini menggunakan metode penelitian hukum normatif dengan pendekatan studi kasus. kualitatif, yaitu dengan analisis bahan yang diperoleh berdasarkan kualitasnya. Penulis akan menganalisis Putusan Nomor 113/Pid.B/2018/PN.Ffk. dapat diambil kesimpulan ialah dasar pertimbangan hakim dalam menjatuhkan hukuman terhadap pelaku tindak pidana dengan sengaja melakukan penambangan pasir secara ilegal yang menimbulkan kerusakan lingkungan dalam Putusan Nomor 113/Pid.B/2018/PN.Ffk, pada prinsipnya diperoleh dari fakta-fakta hukum persidangan yang didasarkan atas alat bukti yang sah diantaranya keterangan saksi-saksi, keterangan terdakwa, keterangan ahli, petunjuk beserta barang bukti yang membuktikan Terdakwa melakukan pertambangan pasir tanpa izin di wilayah pesisir yang mengakibatkan kerusakan lingkungan dan merugikan masyarakat. Hakim juga mempertimbangan hal-hal yang memberatkan dan meringankan Terdakwa.
\end{abstract}

\section{Kata Kunci: Tindak Pidana Pertambangan Pasir, Pertimbangan Hakim, Putusan, Wilayah Pesisir}

Abstract

The act of adjudicating a criminal act is the most important issue and is the center of the criminal justice system. then the formulation of the problem that will be the subject of this writing is what is the basis for the judge's consideration in imposing a sentence against the perpetrator who deliberately mining sand in coastal areas and small islands without a permit? This study uses a normative legal research method with a case study approach. qualitative, namely by analyzing the materials obtained based on their quality. The author will analyze Decision Number 113 / Pid.B / 2018 / PN.Ffk. Conclusions can be drawn is the basis for the judge's consideration in imposing a sentence against the perpetrator of a criminal act by deliberately mining sand illegally which causes environmental damage in Decision Number 113 / Pid.B / 2018 / PN.Ffk, in principle it is obtained from the legal facts of the trial which based on valid evidence, including statements of witnesses, testimony of the defendant, expert testimony, instructions along with evidence proving that the Defendant conducted sand mining without permission in the coastal area which resulted in environmental damage and harm to the community. The Judge also considered matters which incriminated and relieved the Defendant.

Keywords: Sand Mining Crime, Judge's Consideration, Judgment, Coastal Areas 


\section{Pendahuluan}

Indonesia merupakan negara yang kaya akan bahan galian (tambang). Bahan galian itu, meliputi emas, perak, tembaga, minyak dan gas bumi, batu bara, dan lain-lain. Bahan galian itu dikuasai oleh negara. Hak penguasaan negara berisi wewenang untuk mengatur, mengurus dan mengawasi pengelolaan atau pengusahaan bahan galian, serta berisi kewajiban untuk mempergunakannya sebesar-besarnya kemakmuran rakyat. Penguasan oleh negara diselenggarakan oleh pemerintah ${ }^{1}$ seperti pada Pasal 33 ayat (3) UUD 1945 dinyatakan bahwa "bumi dan air dan kekayaan alam yang terkandung di dalamnya dikuasai oleh negara dan digunakan sebesar-besarnya untuk kemakmuran rakyat."

Dalam pengusahaan bahan galian (tambang), pemerintah dapat melaksanakan sendiri dan/atau menunjuk kontraktor apabila diperlukan untuk melaksanakan pekerjaanpekerjaan yang tidak atau belum dapat dilaksanakan sendiri oleh instansi pemerintah. Apabila usaha pertambangan dilaksanakan oleh kontraktor, kedudukan pemerintah adalah memberikan izin kepada kontraktor yang bersangkutan. Izin yang diberikan oleh pemerintah berupa kuasa pertambangan, kontrak karya, perjanjian karya pengusahaan pertambangan batu bara, dan kontrak production sharing. ${ }^{2}$

Sayangnya, tidak semua pertambangan memperoleh izin dari pemerintah. Banyak pertambangan yang dikerjakan secara ilegal tanpa ada pengawasan dari pemerintah sehingga menimbulkan banyak kerugian bagi masyarakat maupun negara karena para penambang tidak membayar pajak. Perusakan alam dan pencemaran lingkungan banyak terjadi karena penambang ilegal tidak memperdulikan kelestarian alam. Salah satu contoh permasalahan pertambangan ilegal yang mengakibatkan kerusakan alam di wilayah pesisir dan pulau-pulau kecil. Wilayah pesisir adalah daerah peralihan antara ekosistem darat dan laut yang dipengaruhi oleh perubahan di darat dan laut. ${ }^{3}$ Dan, pulau-pulau kecil adalah pulau dengan luas lebih kecil atau sama dengan $2.000 \mathrm{~km}^{2}$ (dua ribu kilometer persegi) beserta kesatuan ekosistemnya. ${ }^{4}$ Ekosistem pesisir bersifat sangat dinamis dimana wilayah pesisir merupakan pertemuan antara ekosistem darat dan ekosistem lautan, yang menjadikan wilayah pesisir memiliki nilai strategis, ditunjang oleh potensi kekayaan hayati, seperti sumber daya alam, ekologi, sosial, ekonomi, hingga pariwisata. ${ }^{5}$

Tindakan mengadili suatu tindak pidana merupakan persoalan terpenting dan merupakan pusat dari sistem peradilan pidana. Karena pada tahap ini diputuskan apakah terdakwa dipandang bersalah dan oleh karenanya dipidana, atau tidak bersalah dan oleh karenanya dilepaskan dari segala tuntutan hukum. Dalam konteks penjatuhan pidana, pengadilan bertugas mempertimbangkan secara imbang antara tindak pidana dan pertanggungjawaban pembuat tindak pidana sebagai dasar penjatuhan pidana. Pertimbangan atas tindak pidana dan pertanggungjawaban pidana bertujuan untuk menempatkan "penjatuhan pidana" sebagai pemenuhan kepentingan masyarakat dan individu berdasarkan daad en dader strafrecht. ${ }^{6}$

${ }^{1}$ Salim HS, Hukum Pertambangan di Indonesia, (Jakarta: Raja Grafindo Persada, 2010), hal.1.

${ }^{2}$ Ibid, hal.1-2.

${ }^{3}$ Lihat Pasal 1 ayat (2) Undang-Undang Nomor 27 Tahun 2007 Tentang Pengelolaan Wilayah Pesisir dan Pulau-Pulau Kecil j.o Undang-Undang Nomor 1 tahun 2014 Tentang Perubahan atas UndangUndang Nomor 27 Tahun 2007 Tentang Pengelolaan Wilayah Pesisir dan Pulau-Pulau Kecil.

${ }^{4}$ Lihat Pasal 1 ayat (3) Undang-Undang Nomor 27 Tahun 2007 Tentang Pengelolaan Wilayah Pesisir dan Pulau-Pulau Kecil j.o Undang-Undang Nomor 1 tahun 2014 Tentang Perubahan atas UndangUndang Nomor 27 Tahun 2007 Tentang Pengelolaan Wilayah Pesisir dan Pulau-Pulau Kecil.

${ }^{5}$ Aris Subagiyo, Wawargita P.W dan Dwi M.Z, Pengelolaan Wilayah Pesisir dan Pulau-Pulau Kecil, (Malang: UB Press, 2017), hal.12.

${ }^{6}$ M. Ainul Syamsu, Penjatuhan Pidana \& Dua Prinsip Dasar Hukum Pidana, (Jakarta: Kencana, 2016), hal.1-2. 
Secara normatif, penjatuhan pidana baru dapat dilakukan setelah dibuktikan terdapat keadaan tertentu yang dapat dicelakan kepada pembuat tindak pidana. Pencelaan inilah yang memberikan dasar keabsahan penjatuhan pidana, sehingga setiap orang yang melakukan tindak pidana dengan sengaja atau alpa, maka secara mutatis mutandis ia dianggap bersalah dan dijatuhi pidana. Oleh karenanya, terpenuhinya pembuat tindak pidana. ${ }^{7}$ Dalam mengadili atau menjatuhi hukuman, kewajiban hakim untuk menemukan hukum dan menetapkan hukum terhadap suatu perkara yang diselesaikan. Untuk itu dalam putusan hakim harus memuat dasar pertimbangan hukumnya, maka hakim sebagai figur sentral dalam proses peradilan dituntut agar bisa menegakkan keadilan sehingga keberadaannya mampu memberikan kemanfaatan bagi penyelesaian permaslahan hukum yang terjadi dalam kehidupan dan bernegara. ${ }^{8}$

Seperti dalam Putusan Nomor 113/Pid.B/2018/PN.Ffk, yaitu tindak pidana pertambangan pasir tanpa izin di pesisir pantai. Hakim menetapkan bahwa terdakwa terbukti melakukan tindak pidana Pasal 73 ayat (1) huruf d jo pasal 35 huruf i UndangUndang Nomor 27 Tahun 2007 tentang Pengelolaan Wilayah Pesisir dan Pulau-pulau Kecil, dengan pidana penjara selama 2 (dua) tahun dan pidana denda sebesar Rp2.000.000.000,00 (dua miliar rupiah) dengan ketentuan apabila pidana denda tidak dibayar maka diganti dengan pidana kurungan selama 2 (dua) bulan. Melihat kerusakan lingkungan yang ditimbulkan akibat penambang pasir tanpa izin di pesisir pantai yang dilakukan terdakwa, tentu saja ada hal-hal yang menjadi pertimbangan hakim dalam menjatuhkan sanksi pidana terhadap terdakwa penambang pasir tanpa izin tersebut.

Berdasarkan uraian latar belakang penulisan penelitian ini, maka rumusan masalah yang akan menjadi pokok bahasan dalam penulisan ini adalah bagaimanakah dasar pertimbangan hakim dalam menjatuhkan hukuman terhadap pelaku yang dengan sengaja melakukan penambangan pasir di wilayah pesisir dan pulau-pulau kecil tanpa izin ? (Studi Putusan Nomor 113/Pid.B/2018/PN.Ffk)

\section{Tinjauan Pustaka}

Pidana berasal dari kata straf (bahasa Belanda), yang ada kalanya disebut dengan istilah hukuman. Istilah pidana lebih tepat dari istilah hukuman, karena hukum sudah lazim merupakan terjemahan dari recht. ${ }^{9}$ Untuk pengertian yang sama sering juga digunakan istilah lain yaitu sanksi pidana, penghukuman, pemidanaan, penjatuhan hukuman, pemberian pidana dan hukuman pidana. ${ }^{10}$ Pidana lebih tepat didefinisikan sebagai suatu penderitaan yang sengaja dijatuhkan/diberikan oleh negara pada seseorang atau beberapa orang sebagai akibat hukum (sanksi) baginya atas perbuatannya yang telah melanggar larangan hukum pidana ${ }^{11}$ yang hukuman tersebut dijatuhi dengan setimpal dan bahkan lebih dibandingkan tindakan melawan hukum guna membuat jera masing-masing individu atau kelompok. ${ }^{12}$

Pidana disatu sisi tidak hanya dimaksudkan untuk memberikan penderitaan kepada pelanggar atau membuat jera, tetapi di sisi yang lain juga agar membuat pelanggar dapat kembali hidup bermasyarakat sebagai layaknya. ${ }^{13}$ Tujuan pidana harus memperhatikan

${ }^{7}$ Ibid, hal.4-5.

8 Jonaedi Efendi, Rekonstruksi Dasar Pertimbangan Hukum Hakim, Prenada Media, (Depok: Prenadamedia Group, 2018), hal.11.

${ }^{9}$ Adami Chazawi, Pelajaran Hukum Pidana bagian I, (Jakarta: Rajawali Pers, 2013), hal.24.

${ }^{10}$ Marlina, Hukum Penitensier, (Bandung: Refika Aditama, 2016), hal.13.

${ }^{11}$ Adami Chazawi, Op.cit, hal. 24.

${ }^{12}$ Extrix Mangkepriyanto, Hukum Pidana dan Kriminologi, (Guepedia.com, 2019), hal. 37.

${ }^{13}$ Tolib Setiady, Pokok-Pokok Hukum Penitensier Indonesia, (Bandung: Alfabeta, 2010), hal.21. 
masa dating untuk mencegah agar seseorang atau orang lain sadar untuk tidak mengulangi kesalahan lagi. ${ }^{14}$

Kesengajaan (dolus/opzet) merupakan salah satu bentuk dari kesalahan. Di dalam KUHP tidak dirumuskan mengenai kesengajan tersebut, akan tetapi didalam Memorie van Toelichting (MvT) yang menjadi Kitab Undang-Undang Hukum Pidana Indonesia pada Tahun 1915 dinyatakan bahwa yang dimaksud dengan kesengajaan adalah "menghendaki" dan "mengetahui' (willen en wetens) ${ }^{15}$ yang berbunyi "pidana pada umumnya hendaknya dijatuhkan hanya pada barang siapa melakukan perbuatan yang dilarang, dengan dikehendaki dan diketahui" "16 Mengenai MvT tersebut, Satochid Kartanegara mengutarakan bahwa yang dimaksud dengan opzet willens en weten (dikehendaki dan diketahui) adalah "sengaja yang melakukan suatu perbuatan dengan sengaja harus menghendaki (willen) perbuatan itu serta harus menginsafi atau mengerti (weten) akan akibat dari perbuatan itu"17

Mengenai pengertian kesengajaan, ada 2 (dua) teori mengenai pengertian kesengajan yakni teori kehendak (Wills Theorie) dan teori pengetahuan/membayangkan (Voorstellings Theorie). Menurut teori kehendak, "sengaja" adalah kehendak untuk melakukan suatu perbuatan/tindakan dan kehendak untuk menimbulkan suatu akibat karena perbuatannya itu. Dengan perkataan lain, dapat dikatakan sebagai "sengaja" apabila suatu perbuatan itu dikehendaki, dan akibat perbuatan itu benar-benar menjadi maksud dari perbuatan yang dilakukan. ${ }^{18}$ Sedangkan menurut teori pengetahuan/membayangkan, dirumuskan bahwa "sengaja" adalah apabila suatu akibat dibayangkan sebagai maksud, dan oleh karena itu perbuatan tersebut dilakukan oleh yang bersangkutan sesuai dengan bayangan yang telah dibuatnya lebih dahulu. ${ }^{19}$

Pertambangan adalah suatu kegiatan pengambilan endapan bahan galian berharga dan bernilai ekonomis dari dalam kulit bumi, baik secara mekanis maupun manual, pada permukaan bumi, di bawah permukaan bumi dan di bawah permukaan air. ${ }^{20}$ Berdasarkan Pasal 1 Undang-Undang Nomor 3 Tahun 2020 tentang Perubahan Atas Undang-Undang Nomor 4 Tahun 2009 Tentang Pertambangan Mineral dan Batubara, pengertian pertambangan adalah "sebagian atau seluruh tahapan kegiatan dalam rangka, pengelolaan dan pengusahaan mineral atau batubara yang meliputi penyelidikan umum, eksplorasi, studi kelayakan, konstruksi, penambangan, pengolahan dan/atau pemurnian atau pengembangan dan/atau pemanfaatan, pengangkutan dan penjualan, serta kegiatan pascatambang." 21 Pengertian dari setiap golongan bahan galian tersebut di atas adalah sebagai berikut: ${ }^{22}$

a) Bahan galian golongan strategis (Golongan A), adalah golongan bahan galian yang strategis bagi pertahanan/keamanan negara atau bagi perekonomian negara.

b) Bahan galian golongan vital (Golongan B), adalah bahan galian yang dapat

${ }^{14}$ Marlina, Op.cit, hal.15.

${ }^{15}$ Tolib Setiady, Op.cit, hal.162.

${ }^{16}$ Moeljatno, Asas-Asas Hukum Pidana, Edisi Revisi, (Jakarta: Rineka Cipta, 2019), hal.185.

${ }^{17}$ Leden Marpaung, Asas Teori Praktik Hukum Pidana, (Jakarta: Sinar Grafika, 2018), hal.13.

${ }^{18}$ Teguh Prasetyo, Hukum Pidana, Edisi Revisi, (Jakarta: Rajawali Pers, 2014), hal.97.

${ }^{19}$ Ibid.

${ }^{20}$ Dhanial Iswanto, Statistik Pertambangan Non Minyak dan Gas Bumi, (Jakarta: Badan Pusat Statistik, 2016), hal.4.

${ }^{21}$ Lihat Pasal 1 angka 1 Undang-Undang Nomor 3 Tahun 2020 Tentang Perubahan Atas UndangUndang Nomor 4 Tahun 2009 Tentang Pertambangan Mineral dan Batubara.

${ }^{22}$ Dwi Oktafia Aryanti, Muhammad Ramadhan, dan JS. Murdomo, "Penegakan Hukum Pidana Terhadap Pelaku Penambangan Pasir Secara Illegal”, Jambura Law Review, Vol.2, Issue.01, Januari 2020, hal. 34-35. 
menjamin hajat hidup orang banyak.

c) Bahan galian non strategis dan non vital (Golongan C), adalah bahan galian yang tidak dianggap langsung mempengaruhi hajat hidup orang banyak, baik karena sifatnya maupun karena kecil jumlah depositnya.

Selain itu, penggolongan bahan galian juga didasarkan pada beberapa segi sifat dan keadaan bahan galian yang didasarkan pada beberapa faktor yaitu : terdapatnya sesuatu bahan galian dalam alam (genese), penggunaan bahan galian bagi industri, teknik pengolahan, dan banyak tidaknya deposit bahan galian yang bersangkutan. Sehingga bahan galian yang sifatnya strategis dan vital, tetapi karena jumlah depositnya terlalu kecil maka dikualifikasikan sebagai bahan galian golongan $\mathrm{C}^{23}$ yaitu bahan galian pasir.

Pertambangan pasir atau sering disebut dengan penambangan galian $\mathrm{C}$ adalah merupakan kegiatan usaha penambangan rakyat yang harus memiliki izin pertambangan rakyat (IPR). Izin pertambangan rakyat (IPR) adalah izin untuk melaksanakan usaha pertambangan dalam wilayah pertambangan rakyat dengan luas wilayah dan investasi terbatas $^{24}$ yang dilaksanakan dalam suatu wilayah pertambangan rakyat (WPR) ${ }^{25}$ dengan harus memenuhi kriteria. ${ }^{26}$

Dan dalam menetapkan WPR, bupati/walikota berkewajiban melakukan pengumuman mengenai rencana WPR kepada masyarakat secara terbuka. ${ }^{27}$ Wilayah atau tempat kegiatan tambang rakyat yang sudah dikerjakan tetapi belum ditetapkan sebagai WPR diprioritaskan untuk ditetapkan sebagai WPR. ${ }^{28}$ Mengenai pedoman, prosedur dan penetapan WPR diatur dalam Peraturan Pemerintah ${ }^{29}$ dan mengenai kriteria dan mekanisme penetapan WPR diatur peraturan daerah $\mathrm{kab} / \mathrm{kota}^{30}$

IPR diberikan oleh menteri ${ }^{31}$ kepada orang perseorangan yang merupakan penduduk setempat; atau koperasi yang anggotanya merupakan penduduk setempat. Pemohon harus menyampaikan permohonan kepada menteri. ${ }^{32}$ Luas wilayah untuk 1 (satu) IPR yang dapat diberikan kepada orang perseorangan ialah paling luas 5 (lima) hektare; dan kepada koperasi ialah paling luas 10 (sepuluh) hektare. IPR diberikan untuk jangka

${ }^{23}$ Ibid, hal.35.

${ }^{24}$ Lihat Pasal 1 angka 10 Undang-Undang Nomor 3 Tahun 2020 Tentang Perubahan Atas UndangUndang Nomor 4 Tahun 2009 Tentang Pertambangan Mineral dan Batubara.

${ }^{25}$ Lihat Pasal 20 Undang-Undang Nomor 4 Tahun 2009 Tentang Pertambangan Mineral dan Batubara jo Undang-Undang Nomor 3 Tahun 2020 Tentang Perubahan Atas Undang-Undang Nomor 4 Tahun 2009 Tentang Pertambangan Mineral dan Batubara.

${ }^{26}$ Lihat Pasal 22 Undang-Undang Nomor 3 Tahun 2020 Tentang Perubahan Atas Undang-Undang Nomor 4 Tahun 2009 Tentang Pertambangan Mineral dan Batubara.

27 Lihat Pasal 23 Undang-Undang Nomor 4 Tahun 2009 Tentang Pertambangan Mineral dan Batubara jo Undang-Undang Nomor 3 Tahun 2020 Tentang Perubahan Atas Undang-Undang Nomor 4 Tahun 2009 Tentang Pertambangan Mineral dan Batubara.

${ }^{28}$ Lihat Pasal 24 Undang-Undang Nomor 4 Tahun 2009 Tentang Pertambangan Mineral dan Batubara jo Undang-Undang Nomor 3 Tahun 2020 Tentang Perubahan Atas Undang-Undang Nomor 4 Tahun 2009 Tentang Pertambangan Mineral dan Batubara.

29 Lihat Pasal 25 Undang-Undang Nomor 4 Tahun 2009 Tentang Pertambangan Mineral dan Batubara jo Undang-Undang Nomor 3 Tahun 2020 Tentang Perubahan Atas Undang-Undang Nomor 4 Tahun 2009 Tentang Pertambangan Mineral dan Batubara.

${ }^{30}$ Lihat Pasal 26 Undang-Undang Nomor 4 Tahun 2009 Tentang Pertambangan Mineral dan Batubara jo Undang-Undang Nomor 3 Tahun 2020 Tentang Perubahan Atas Undang-Undang Nomor 4 Tahun 2009 Tentang Pertambangan Mineral dan Batubara.

${ }^{31}$ Menteri adalah menteri yang menyelenggarakan urusan pemerintahan di bidang pertambangan mineral dan batubara (Lihat Pasal 1 angka 38 Undang-Undang Nomor 3 Tahun 2020 Tentang Perubahan Atas Undang-Undang Nomor 4 Tahun 2009 Tentang Pertambangan Mineral dan Batubara.

32 Lihat Pasal 67 Undang-Undang Nomor 3 Tahun 2020 Tentang Perubahan Atas Undang-Undang Nomor 4 Tahun 2009 Tentang Pertambangan Mineral dan Batubara. 
waktu paling lama 10 (sepuluh) tahun dan dapat diperpanjang 2 (dua) kali masing-masing 5 (lima) tahun. ${ }^{33}$ Pemegang IPR memiliki hak ${ }^{34}$ dan juga memiliki kewajiban ${ }^{35}$ sesuai peraturan perundang-undangan. Pemegang IPR dilarang memindahtangankan IPR kepada pihak lain. ${ }^{36}$ Tata cara dan syarat pemberian IPR diatur berdasarkan Peraturan Pemerintah $^{37}$ Nomor 23 Tahun 2010 tentang Pelaksanaan Kegiatan Usaha Pertambangan Mineral dan Batubara.

\section{Metode}

Penelitian ini menggunakan metode penelitian hukum normatif dengan pendekatan studi kasus. Metode penelitian hukum normatif adalah metode penelitian hukum dengan sumber kepustakaan dan menganalisis sumber bahan-bahan terhadap asas-asas hukum dan normanorma hukum yang terdapat pada peraturan perundang-undangan yang mempunyai hubungan dengan pokok-pokok permasalahan penelitian ini. Dalam penelitian ini analisis bahan yang digunakan ialah dengan cara kualitatif, yaitu dengan analisis bahan yang diperoleh berdasarkan kualitasnya. Penulis akan menganalisis Putusan Nomor 113/Pid.B/2018/PN.Ffk tentang tindak penambangan pasir di wilayah pesisir dan pulaupulau kecil secara ilegal yang menimbulkan kerusakan lingkungan, yang selanjutnya penulis akan membedah buku-buku dan undang-undang yang berkaitan dengan pokok permasalah. Lalu selanjutnya penulis akan uraikan dalam bentuk kalimat-kalimat yang tersusun secara sistematis, kemudian dilakukan pembahasan dan penafsiran yang akhirnya dapat ditarik kesimpulan tentang pokok permasalahan yang penulis teliti.

\section{Pembahasan Dan Hasil}

Untuk menjatuhkan putusan terhadap pelaku tindak pidana, hakim membuat pertimbangan-pertimbangan. Pertimbangan-pertimbangan hakim tersebut merupakan fakta-fakta yang terungkap dalam pemeriksaan di persidangan yang secara berturut-turut berupa keterangan saksi-saksi, keterangan ahli, petunjuk dan keterangan terdakwa yang telah dihubungkan dengan dakwaan jaksa penuntut umum atas diri Terdakwa.

Penulis setuju dengan pertimbangan hakim terhadap barang bukti berupa pasir 200 (dua ratus) karung yang dirampas untuk negara, karena memiliki nilai ekonomis. Penulis juga setuju dengan pertimbangan hakim mengenai barang bukti berupa kapal KMB. Syafar yang merupakan satu-satunya alat untuk mencari nafkah bagi Terdakwa dan pada temantemannya Terdakwa untuk digunakan mencari ikan sehingga Terdakwa menyediakan lapangan kerja sebagai nelayan sehingga bisa memberantas kemiskinan, maka ditetapkan oleh Majelis hakim agar barang bukti Kapal tersebut diserahkan kebali kepada pemiliknya ialah Terdakwa La Sudin. Walaupun barang bukti kapal KMB. Syafar memiliki nilai ekonomis dan juga bahwa barang bukti kapal tersebut merupakan alat yang digunakan Terdakwa dalam melakukan tindak pidana pertambangan pasir. Namun, melihat keadaan sosial ekonomi Terdakwa sebagai nelayan dan juga sebagai tulang punggung keluarga

${ }^{33}$ Lihat Pasal 68 Undang-Undang Nomor 3 Tahun 2020 Tentang Perubahan Atas Undang-Undang Nomor 4 Tahun 2009 Tentang Pertambangan Mineral dan Batubara.

${ }^{34}$ Lihat Pasal 69 Undang-Undang Nomor 4 Tahun 2009 Tentang Pertambangan Mineral dan Batubara jo Undang-Undang Nomor 3 Tahun 2020 Tentang Perubahan Atas Undang-Undang Nomor 4 Tahun 2009 Tentang Pertambangan Mineral dan Batubara.

${ }^{35}$ Lihat Pasal 70 Undang-Undang Nomor 3 Tahun 2020 Tentang Perubahan Atas Undang-Undang Nomor 4 Tahun 2009 Tentang Pertambangan Mineral dan Batubara.

${ }^{36}$ Lihat Pasal 70A Undang-Undang Nomor 3 Tahun 2020 Tentang Perubahan Atas Undang-Undang Nomor 4 Tahun 2009 Tentang Pertambangan Mineral dan Batubara.

${ }^{37}$ Lihat Pasal 72 Undang-Undang Nomor 3 Tahun 2020 Tentang Perubahan Atas Undang-Undang Nomor 4 Tahun 2009 Tentang Pertambangan Mineral dan Batubara. 
dengan mempunyai tanggungan istri dan anak yang masih kecil, dan juga Terdakwa belum pernah dihukum. Jika hakim mengabulkan tuntutan penuntut umum dengan merampas barang bukti kapal tersebut untuk negara. Maka teman-teman Terdakwa tidak memiliki pekerjaan, dan akan menimbulkan emosional dalam diri teman-teman Terdakwa yang kesulitan dalam memenuhi kebutuhan hidup. Terlebih lagi, setelah Terdakwa bebas nanti, Terdakwa akan kesulitan untuk memenuhi kehidupan diri sendiri dan juga keluarganya. Itu akan mengakibatkan munculnya emosional didalam diri Terdakwa, yang kemungkinan akan melakukan tindak pidana kembali. Mengingat bahwa, tujuan pemidanaan bukan hanya saja sebagai pembalasan terhadap Terdakwa tapi juga harus memperhatikan masa yang akan datang.

Namun menurut penulis, seharusnya hakim juga mempertimbangankan akibat atas perbuatan Terdakwa yaitu atas perbuatannya bukan hanya mengakibatkan kerusakan lingkungan pada pantai Kampung Siboru saja, namun juga mengakibatkan kerugian pada masyarakat ataupun para nelayan disekitar pantai Kampung Siboru. Berdasarkan keterangan Saksi Yeskel Hombore, Saksi Abraham Patipi dan Saksi Yunus Hombore sebagai perwakilan dari masyarakat dan para nelayan yang berada disekitar pesisir pantai Kampung Siboru menerangkan bahwa akibat yang ditimbulkan atas perbuatan Terdakwa ialah abrasi atau pengikisan terhadap bibir pantai dan ikan-ikan semuanya menjauh dari area bibir pantai yang merugikan masayarakat ataupun para nelayan. Dan begitu pula dengan keterangan Saksi Ahli Ramly Makamban. Kerusakan lingkungan yang terjadi pada pesisir pantai Kampung Siboru yang letaknya termasuk dipulau-pulau kecil Indonesia yaitu Kabupaten Fakfak, seharusnya menjadi permasalahan penting aturan atau hukuman pidananya diperberat. Guna untuk melindungi wilayah pesisir dan pulau-pulau kecil di Indonesia, karena wilayah pesisir dan pulau-pulau kecil memiliki sumber daya alam yang cukup tinggi dan sangat penting bagi pengembangan kesejahteraan masyarakat.

Dalam surat dakwaan penuntut umum, diuraikan identitas Terdakwa dan jelas bahwa umur Terdakwa terbilang masih muda dan sangat mengerti bahwa apapun yang dilakukan didalam kehidupan pasti memiliki aturan ataupun larangan. Terlebih dalam melakukan pertambangan pasir, sangat jelas jika ingin melakukan kegiatan yang dimana kegiatan tersebut mengambil tanpa izin apalagi mengambil pasir yang jelas miliki negara, ialah perbuatan dilarang. Namun, Terdakwa tetap melakukan pertambangan tanpa izin dari pemerintah bahkan lebih dari 1 (satu) tahun. Terdakwa juga sudah diperingati oleh Saksi Akbar Tamsil dan Saksi Sabas Hombore mengenai adanya edaran ataupun larangan pertambangan pasir oleh Pemerintah Kabupaten Fakfak. Namun Terdakwa tetap melakukan pertambangan pasir tanpa memiliki izin.

Jadi seharusnya alasan-alasan diatas termasuk dalam hal-hal yang memberatkan bagi Terdakwa. Dan dengan begitu, Majelis hakim akan menjatuhkan hukuman pidana pokok yang setimpal atas perbuatan Terdakwa. Karena hukuman yang dijatuhi oleh majelis hakim termasuk minimum. Pemidanaan harus bersifat proposional yaitu mengandung prinsip dan tujuan pemidanaan antara lain sebagai memperbaiki, pendidikan, pencegahan, dan pemberantasan. Dengan begitu, masyarakat menjadi takut untuk melakukan pertambangan tanpa izin, dan akan mentaati peraturan yang ada dengan mengikuti tata cara untuk memiliki izin pertambangan. Masyarakat juga menjadi mengerti bahwa pertambangan harus dilakukan dengan aturan agar tidak merusak lingkungan dan tidak berakibat buruk dimasa yang akan datang.

Putusan Nomor 113/Pid.B/2018/PN.Ffk adalah perkara tentang pertambangan pasir di wilayah pesisir pantai yang dilakukan oleh La Sudin tanpa memiliki izin dari pemerintah yang atas perbuatannya mengakibatkan kerusakan lingkungan di pesisir pantai dan merugikan masyarakat setempat. Terdakwa dinyatakan terbukti bersalah oleh Majelis 


\section{PATIK : JURNAL HUKUM Vol : 10 No. 1, April 2021, Hal 51 - 60}

Hakim Pengadilan Negeri Fakfak melakukan tindak pidana dengan sengaja melakukan penambangan pasir secara ilegal yang menimbulkan kerusakan lingkungan sebagaimana diatur dan diancam pidana dalam Pasal 73 ayat (1) huruf d jo Pasal 35 huruf i UndangUndang Nomor 27 Tahun 2007 tentang Pengelolaan Wilayah Pesisir dan Pulau-pulau Kecil.

Putusan majelis hakim terhadap kasus tindak pidana dengan sengaja melakukan penambangan pasir secara ilegal yang menimbulkan kerusakan lingkungan yang dilakukan oleh Terdakwa La Sudin, menurut penulis, putusan hakim dengan menjatuhkan pidana penjara 2 (dua) tahun kepada Terdakwa, terlalu ringan dan dalam hukuman pidana denda Rp2.000.000.000,00 (dua miliar rupiah) yang jika tidak dapat dibayar maka pidana denda tersebut diganti dengan pidana kurungan selama 2 (dua) bulan. Menurut penulis hukuman tersebut tidak sebanding dengan jumlah pidana denda.

Pada Pasal 30 KUHP dikatakan bahwa pidana kurungan pengganti sekali-kali tidak boleh lebih dari delapan bulan. Pada tindak pidana dalam kasus ini, berdasarkan Pasal 73 ayat (1) huruf d jo Pasal 35 huruf i UU No. 27 Tahun 2007 tentang Pengelolaan Wilayah Pesisir dan Pulau-pulau Kecil, dimana pidana denda minimum ialah Rp2.000.000.000,00 (dua miliar rupiah) dan maksimal Rp10.000.000.000,00 (sepuluh miliar rupiah). Maka menurut Penulis, pidana kurungan pengganti selama 2 (dua) bulan terlalu ringan untuk denda Rp2.000.000.000,00 (dua miliar rupiah).

Mengingat perbuatan Terdakwa La Sudin melakukan dengan sengaja pertambangan pasir tanpa memiliki izin, yang bahkan sudah diperingati oleh Saksi Akbar Tamsil dan Saksi Sabas Hombore kalau dilarang melakukan pertambangan pasir di Kabupaten Fakfak dan atas perbuatan Terdakwa mengakibatkan kerusakan lingkungan di area pantai dan merugikan masyarakat dan para nelayan yang berada di sekitar pantai. Jadi menurut Penulis, hukuman pidana pokok yakni pidana penjara dan pidana denda dalam perkara ini belum setimpal dengan perbuatan Terdakwa yang merusak lingkungan pesisir pantai dan merugikan atau berakibat buruk kepada masyarakat ataupun para nelayan. Dan mengingat bahwa putusan hakim juga berlaku bagi peristiwa-peristiwa lainnya yang serupa yang terjadi dikemudian hari. Seperti keterangan saksi masyarakat dan nelayan, bahwa mereka sering melarang para penambang pasir. Jelas bahwa penambangan pasir di pesisir pantai memiliki jumlah yang lumayan banyak. Maka putusan hakim dalam kasus perkara ini akan menjadi peringatan kepada penambang ilegal lainnya dan juga kepada masyarakat agar tidak melakukan pertambangan pasir ilegal. Namun sayangnya putusan hukuman hakim masih terbilang ringan.

Penulis setuju dengan putusan hakim yang memutus bahwa barang bukti pasir 200 (dua ratus) karung dirampas oleh negara karena memiliki nilai ekonomis. Dan Penulis setuju juga dengan putusan Hakim bahwa barang bukti berupa kapal KMB. Syafar yang dikembalikan kepada La Sudin walaupun kapal tersebut memiliki nilai ekonomis dan merupakan alat dalam melakukan tindak pidana pertambangan pasir tanpa izin. Mengingat, karena tujuan pemidanaan bukan semata-mata memberi pembalasan kepada pelaku tindak pidana, melainkan menjadikan pelaku tindak pidana menjadi manusia yang lebih baik, dan tidak ingin melakukan perbuatan tindak pidana lagi. Dan tujuan pidana juga harus memperhatikan masa yang akan datang.

\section{Kesimpulan Dan Saran}

Berdasarkan hasil pembahasan, maka dapat diambil kesimpulan ialah dasar pertimbangan hakim dalam menjatuhkan hukuman terhadap pelaku tindak pidana dengan sengaja melakukan penambangan pasir secara ilegal yang menimbulkan kerusakan lingkungan dalam Putusan Nomor 113/Pid.B/2018/PN.Ffk, pada prinsipnya diperoleh dari 
fakta-fakta hukum persidangan yang didasarkan atas alat bukti yang sah diantaranya keterangan saksi-saksi, keterangan terdakwa, keterangan ahli, petunjuk beserta barang bukti yang membuktikan Terdakwa melakukan pertambangan pasir tanpa izin di wilayah pesisir yang mengakibatkan kerusakan lingkungan dan merugikan masyarakat. Hakim juga mempertimbangan hal-hal yang memberatkan dan meringankan Terdakwa. Pertimbangan hakim juga tidak lepas dari pendekatan-pendekatan hukum yaitu pendekatan normative (asas-asas hukum, norma-norma hukum, dan aturan hukum tertulis dan tidak tertulis) dan pendekatan empiris (nilai-nilai moral diantaranya moral keadilan). Namun dalam pertimbangan hakim tidak mempertimbangkan bahwa perbuatan Terdakwa berakibat buruk untuk masyarakat dan nelayan di sekitar pesisir pantai yang sudah diterangkan oleh saksisaksi dan saksi ahli. Hakim selaku pemutus dalam menjatuhkan hukuman hendaknya lebih memperhatikan fakta-fakta hukum di persidangan dan juga harus lebih tegas dalam memutus perkara pertambangan pasir yang ilegal, hakim juga harus memperhatikan .

\section{DAFTAR PUSTAKA}

\section{Buku}

Ali, Mahrus. Dasar-Dasar Hukum Pidana. (Jakarta: Sinar Grafika, 2015).

Chazawi, Adami. Pelajaran Hukum Pidana bagian I. (Jakarta: Rajawali Pers, 2013).

Efendi, Jonaedi. Rekonstruksi Dasar Pertimbangan Hukum Hakim. (Jakarta: Prenada Media., 2018). Google Books

Hamzah, Andi. Asas-Asas Hukum Pidana. (Jakarta: Rineka Cipta, 2018).

Hiariej, Eddy O.S. Prinsip-Prinsip Hukum Pidana (Edisi Revisi). (Yogyakarta: Cahaya Atma Pustaka, 2016).

HS, Salim. Hukum Pertambangan di Indonesia. (Jakarta: PT. Raja Grafindo Persada, 2010).

HS, Salim. Hukum Pertambangan di Indonesia. (Jakarta: Sinar Grafika, 2012).

Ilyas, Amir. Asas-Asas Hukum Pidana Memahami Tindak Pidana dan Pertanggungjawaban Pidana sebagai Syarat Pemidanaan. (Yogyakarta: Rangkang Education Yogyakarta \& PuKAP-Indonesia, 2012).

Iswanto, Dhanial. Statistik Pertambangan Non Minyak dan Gas Bumi. (Jakarta: Badan Pusat Statistik, 2016).

Mangkepriyanto, Extrix. Hukum Pidana dan Kriminologi. (Guepedia.com., 2019). Google Books

Mappiasse, Syarif. Logika Hukum Pertimbangan Putusan Hakim. (Jakarta: Kencana, 2015).

Marlina. Hukum Penitensier. (Bandung: Refika Aditama, 2016).

Marpaung, Leden. Asas Teori Praktik Hukum Pidana. (Jakarta: Sinar Grafika, 2018).

Marzuki, Peter Mahmud. Penelitian Hukum. (Jakarta: Kencana Prenada Media Group, 2015).

Moeljatno. Asas-Asas Hukum Pidana (Edisi Revisi). (Jakarta: Rineka Cipta, 2019).

Prasetyo, Teguh. Hukum Pidana (Edisi Revisi). (Jakarta: Rajawali Pers, 2014).

Rudianto. Buku Ajar Pengelolaan Wilayah Pesisir dan Laut Terpadu. (Jawa Timur: Uwais Inspirasi Indonesia., 2018). Google Books

Rudianto, H. Restorasi Ekosistem Pesisir. (Malang: UB Press., 2017). Google Books

Setiady, Tolib. Pokok-Pokok Hukum Penitensier Indonesia. (Bandung: Alfabeta, 2010). 
PATIK : JURNAL HUKUM Vol : 10 No. 1, April 2021, Hal 51 - 60

Subagiyo, Aris, Wawargita P.W. dan Dwi M.Z. Pengelolaan Wilayah Pesisir dan Pulaupulau Kecil. (Malang: UB Press., 2017). Google Books

Suyanto. Pengantar Hukum Pidana. (Sleman: Deepublish., 2018). Google Books

Syamsu, M. Ainul. Penjatuhan Pidana \& Dua Prinsip Dasar Hukum Pidana. (Jakarta: Kencana., 2016). Google Books

Tomalili, Rahmanuddin. Hukum Pidana. (Sleman: Deepublish., 2019). Google Books

Wibowo, Bambang Ary, Galuh Wahyu Kumalasari dan Ismaya Salindri. Sistem Hukum dan Perubahan Sosial di Indonesia. (Surakarta: UNS Press, 2014).

\section{Jurnal}

Anshari. Faktor-faktor Pertimbangan Hakim dalam Menjatuhkan Putusan Pidana terhadap Pelaku Tindak Pidana Narkotika di Pengadilan Negeri Yogyakarta. Res Judicata Vol. 1 No. 1, Juni 2018.

Aryanti, Dwi Oktafia, Muhammad Ramadhan dan JS Murdomo. Penegakan Hukum Pidana Terhadap Pelaku Penambangan Pasir Secara Ilegal. Jambura Law Review Vol. 2 No. 01, Januari 2020.

Hasibuan, Pondang, Sahat Benny Risman Girsang, Erni Juniria Harefa, Janpatar Simamora, and Herlina Manullang. 2020. "AKIBAT HUKUM PENCABUTAN BERITA ACARA PEMERIKSAAN SAKSI DI DEPAN PERSIDANGAN DALAM TINDAK PIDANA NARKOTIKA (Studi Putusan Nomor 201/Pid.Sus/2018/PN Simalungun)". Nommensen Journal of Legal Opinion 1 (01):129-38. https://doi.org/10.51622/njlo.v1i01.341.

Mahzaniar. Dasar Pertimbangan Hakim dalam Menjatuhkan Putusan Kasus Perjudian. Jurnal Administrasi Publik Vol. 7 No. 2, Desember 2017.

Simamora, Janpatar., Tafsir Makna Negara Hukum dalam Perspektif Undang-Undang Dasar Negara Republik Indonesia Tahun 1945, Jurnal Dinamika Hukum FH Universitas Jenderal Soedirman, Vol. 14 No. 3 September 2014, hlm. 547-561

Sucantra, I Made Bayu, I Nyoman Sujana dan Luh Putu Suryani. Sanksi Pidana Terhadap Tindak Pidana Pertambangan (Menurut Undang-Undang Nomor 4 Tahun 2009 Tentang Minera). Jurnal Analogi Hukum Vol. 1 No. 3, 2019. 